\title{
Tintinnid ciliate diversity in the Mediterranean Sea: longitudinal patterns related to water column structure in late spring-early summer
}

\author{
John R. Dolan* \\ Smithsonian Environmental Research Center, PO Box 28, Edgewater, Maryland 21037, USA \\ and
}

Marine Microbial Ecology Group, CNRS ESA 7076, Station Zoologique, BP 28, 06230 Villefranche-sur-Mer, France

\begin{abstract}
Globally, north-south gradients in diversity are well known, and in the world ocean they have been related to north-south gradients in water column structure. Here diversity in planktonic ciliates, both taxonomic and morphological, is explored in the Mediterranean Sea, which displays west-east gradients in the water column characteristics of chlorophyll concentrations and distributions. Tintinnids, which are loricate planktonic ciliates, were enumerated and identified in samples from 23 stations between 2 and $32^{\circ} \mathrm{E}$, obtained from the Catalan Sea in June 1993 and from a crossMediterranean transect in May-June 1996. From west to east, concentrations of tintinnids showed little variability, while numbers of species and genera, as well as diversity indices ( $H^{\prime}$ values), increased. These parameters were positively related to depths of the chlorophyll maximum layer and negatively correlated with chlorophyll concentrations. Corresponding to the west to east increases in diversity were increases in community averages of lorica oral diameter and overall length, again positively correlated to deepening of chlorophyll maximum depths, and negatively related to average chlorophyll concentrations. Morphological diversity was related to species diversity, not as variability in lorica oral diameters, but as variability in average lorica length. In the Mediterranean Sea, a gradient of taxonomic and morphological diversity is relatable to a specific feature of the water column, the depth of the chlorophyll maximum layer. Trophic specialization as a dominant mechanism underlying diversity was not supported by data on lorica oral diameters.
\end{abstract}

KEY WORDS: Biodiversity · Plankton · Latitudinal gradient

\section{INTRODUCTION}

Tinitinnid ciliates are a common, and due to their loricas, distinctive component of plankton communities, which explains why, among ciliates, they have long been catalogued in plankton collections and the subject of taxonomic monographs (e.g., Jörgensen 1924). In the 1970s, the development began of an extensive literature on their ecology due to the 'changing paradigm' of planktonic food webs (Pomeroy 1974). The paradigm focused atttention on pico- and nanoplankton; tintinnids, as consumers of pico- and nanoplankton, were recognized as potentially important in marine food webs.

*E-mail: dolan@obs-vlfr.fr
Investigations of feeding revealed that tintinnid ciliates ingest a large variety of pico- and nano-sized prey, ranging in size from about $2 \mu \mathrm{m}$ to particles about half the diameter of their lorica oral openings (e.g., Spittler 1973, Heinbokel 1978, Rassoulzadegan 1978, Rassoulzadegan \& Etienne 1981, Capriulo 1982). Complexities in feeding, such as selective ingestion, among different dinoflagellates were shown (e.g., Stoecker et al. 1981). Field investigations suggested that tintinnids could remove large portions (10 to $27 \%$ ) of daily primary production in some coastal waters (e.g., Heinbokel \& Beers 1979, Capriulo \& Carpenter 1983). Detailed studies were conducted on tintinnid energetics, revealing high potential growth rates even among large species, and high weight-specific excretion rates (e.g., Stoecker et al. 1983, Verity 1985, 1987). Data were gathered 
from both the field and lab showing the efficient explotation of tintinnids by higher trophic levels (Robertson 1983, Turner \& Anderson 1983, Stoecker \& Sanders 1985).

In recent years however, while ciliate microzooplankton have become acknowledged as playing a pivotal role in most planktonic food webs (e.g., Pierce \& Turner 1992), interest in the ecology of tintinnid ciliates apparently has waned. This is due most likely to findings that 'naked' oligotrich ciliate taxa are generally much more abundant than tintinnids. In a large variety of systems, tintinnid ciliates represent a small fraction ( $\leq 10 \%$ of cell numbers or biomass) of the ciliate community (e.g., Dolan \& Marrasé 1995, Gifford et al. 1995, Caron \& Dennett 1999). Thus, the activities of tintinnids such as grazing or excretion are probably much less important quantitatively than those of the naked oligotrich taxa such as Strombidium, Strobilidium, etc.

While the tintinnid ciliate component of microzooplankton communities may play a relatively minor role in processes such as carbon flux or nutrient regeneration, they are ideal organisms for the study of changes in the structure or composition of microzooplankton communities (Thompson et al. 1999). This is because changes in the composition of tintinnid communities can easily be detected as species identifications can be made using lorica morphology. Tinitinnids can be identified by examining specimens in plankton settling chambers; in contrast, identification of naked oligotrichs requires mounting on slides, cytological staining and examination under high magnification (i.e., protargol silver staining; Montagnes \& Lynn 1987, 1991).

Previous studies of Mediterranean ciliate microzooplankton, which focused on determination of the magnitudes of ciliate standing stocks, revealed a surprising variety of forms of tintinnid ciliates (Dolan \& Marrasé 1995, Dolan et al. 1999). A gradient from west to east of increasing tintinnid diversity was apparent based on the number of different species encountered as a function of the number of individuals examined in different Mediterranean basins (Dolan et al. 1999). Here a detailed analysis of patterns in tintinnid diversity, based on data gathered from 2 springtime oceanographic campaigns, is attempted.

The interest of establishing diversity patterns among Mediterranean tintinnids is 2-fold. First, for tintinnids some general biogeographic patterns, i.e., cold versus warm water taxa (Zietzschel 1982), or identification of genera as cosmopolitan, neritic, etc. (Pierce \& Turner 1993), have been established but quantitative data on tintinnid diversity are very rare (Cariou et al. 1999, Thompson et al. 1999). Second, the Mediterranean Sea represents an especially interesting system as it can be considered a model of the world ocean, oriented west- east rather than north-south, in terms of both water mass formations and circulation patterns, as well as in gradients of primary production and seasonality of primary production (Bethoux et al. 1998). Therefore, west to east patterns among Mediterranean taxa provide a means to examine the generality of mechanisms proposed to account for north-south trends found among taxa in the world ocean.

For example, tintinnid diversity was described along a north-south transect in the southwestern Atlantic between 34 and $58^{\circ} \mathrm{S}$ (Thompson et al. 1999). The authors presented evidence of a general trend of decreasing numbers of species and specific diversity, attributed to differences in water column structure, as Antarctic waters were approached (Thompson et al. 1999). In another recent report, Rutherford et al. (1999) found, for the Atlantic Ocean, a close curvi-linear association between numbers of species of planktonic foraminifera and sea surface water temperature, and explained the link as reflecting an association between water column structure and diversity. They found that middle latitudes showed higher numbers of species than both the tropics and high latitude waters and explained this as reflecting the fact that middle latitude water columns are characterised by deep, permanent thermoclines compared to both tropical waters with shallow permanent thermoclines and high latitude waters with seasonal thermoclines; thus, vertical niche seperation was invoked as the basic mechanism allowing diversity (Rutherford et al. 1999).

Here data are presented on tintinnid diversity in a system which displays a distinct gradient in water column structure in the form of the depth of the chlorophyll maximum layer as well as chlorophyll concentrations. Diversity patterns are explored in terms of taxonomy (i.e., numbers of species, numbers of genera, the Shannon index $H^{\prime}$ ) as well as in terms of morphology (i.e., dimensions of tintinnid loricas).

\section{METHODS AND MATERIALS}

Data presented and analysed on tintinnid ciliates are from samples obtained from 2 oceanographic cruises, Mesoscale 93 and Minos. For both cruises, results on overall ciliate community composition and distribution have appeared previously. For the Mesoscale 93 cruise, details of water column characteristics, sampling protocols, and sample processing appear in a report which focused on vertical distribution of ciliate biomass (Dolan \& Marrasé 1995). Here, data from 6 stations between the coast of Spain and the Balearic Islands (between approx. 2 and $3^{\circ} \mathrm{E}$ ) sampled on 14 June 1993 are presented. For the Minos cruise, study details appear in Dolan et al. (1999), which focused on longi- 
tudinal trends in ciliate biomass in the Mediterranean Sea. Here, data are presented from the analysis of samples from 17 stations between the French coast $\left(6^{\circ} \mathrm{E}\right)$ and the Levantin basin $\left(32^{\circ} \mathrm{E}\right)$ obtained from 24 May to 25 June 1996. Station locations and characteristics are given in Table 1. Below, water column sampling and sample processing for ciliates, which were identical for the 2 cruises, are briefly summarized.

Niskin bottle samples were obtained from 6 to 12 depths between the surface to below the chlorophyll maximum layer. Samples $(500 \mathrm{ml})$ were preserved with acid Lugol's solution (2\% final conc.) and stored refrigerated and in darkness, except during transport, until processed. Following the protocol outlined in Dolan \& Marrasé (1995), the $500 \mathrm{ml}$ samples were concentrated using sedimentation to $75-100 \mathrm{ml}$ and aliquots of the concentrate, equivalent to $250-500 \mathrm{ml}$ of whole water, were settled in settling chambers and examined using an inverted microscope. Tintinnids were identified based on lorica morphology using the species descriptions of Balech (1959), Campbell (1942), Jörgensen (1924), and Kofoid \& Campbell (1929, 1939). Lorica dimensions were measured with an ocular micrometer.

It should be noted that, while tintinnid species identifications are based on lorica morphology because the

Table 1. Station locations and characteristics. No. of bottles: number of different depths sampled between $5 \mathrm{~m}$ and the bottom; $\mathrm{Chl}$ max: maximum depth in $\mathrm{m}(Z)$ and maximum chlorophyll concentration in $\mathrm{ng} \mathrm{l}^{-1}$

\begin{tabular}{|ccccrr|}
\hline Stn & Location & $\begin{array}{c}\text { Date } \\
(\mathrm{mo} / \mathrm{d} / \mathrm{yr})\end{array}$ & $\begin{array}{c}\text { No. of bottles/ } \\
\text { bottom depth }(\mathrm{m})\end{array}$ & \multicolumn{2}{c|}{$\begin{array}{c}\text { Chl max. } \\
\text { Conc. }\end{array}$} \\
\hline 1 & $41^{\circ} 11^{\prime} \mathrm{N}, 2^{\circ} 19^{\prime} \mathrm{E}$ & $6 / 14 / 93$ & $9 / 200$ & 50 & 1280 \\
2 & $41^{\circ} 07^{\prime} \mathrm{N}, 2^{\circ} 23^{\prime} \mathrm{E}$ & $6 / 14 / 93$ & $8 / 105$ & 44 & 1210 \\
3 & $40^{\circ} 57^{\prime} \mathrm{N}, 2^{\circ} 30^{\prime} \mathrm{E}$ & $6 / 14 / 93$ & $9 / 200$ & 40 & 980 \\
4 & $40^{\circ} 48^{\prime} \mathrm{N}, 2^{\circ} 38^{\prime} \mathrm{E}$ & $6 / 14 / 93$ & $8 / 200$ & 30 & 1280 \\
5 & $40^{\circ} 39^{\prime} \mathrm{N}, 2^{\circ} 45^{\prime} \mathrm{E}$ & $6 / 14 / 93$ & $9 / 200$ & 50 & 900 \\
6 & $40^{\circ} 35^{\prime} \mathrm{N}, 2^{\circ} 49^{\prime} \mathrm{E}$ & $6 / 14 / 93$ & $8 / 200$ & 40 & 1170 \\
7 & $41^{\circ} 00^{\prime} \mathrm{N}, 6^{\circ} 10^{\prime} \mathrm{E}$ & $5 / 24 / 96$ & $6 / 80$ & 50 & 1038 \\
8 & $39^{\circ} 10^{\prime} \mathrm{N}, 6^{\circ} 10^{\prime} \mathrm{E}$ & $5 / 25 / 96$ & $6 / 90$ & 80 & 302 \\
9 & $38^{\circ} 00^{\prime} \mathrm{N}, 6^{\circ} 10^{\prime} \mathrm{E}$ & $5 / 28 / 96$ & $6 / 90$ & 50 & 1792 \\
10 & $37^{\circ} 00^{\prime} \mathrm{N}, 9^{\circ} 00^{\prime} \mathrm{E}$ & $5 / 29 / 96$ & $6 / 90$ & 40 & 598 \\
11 & $41^{\circ} 30^{\prime} \mathrm{N}, 10^{\circ} 40^{\prime} \mathrm{E}$ & $6 / 2596$ & $6 / 120$ & 80 & 458 \\
12 & $38^{\circ} 00^{\prime} \mathrm{N}, 11^{\circ} 20^{\prime} \mathrm{E}$ & $5 / 30 / 96$ & $6 / 90$ & 50 & 963 \\
13 & $36^{\circ} 30^{\prime} \mathrm{N}, 13^{\circ} 15^{\prime} \mathrm{E}$ & $5 / 31 / 96$ & $6 / 90$ & 70 & 451 \\
14 & $36^{\circ} 00^{\prime} \mathrm{N}, 15^{\circ} 45^{\prime} \mathrm{E}$ & $6 / 1 / 96$ & $6 / 90$ & 80 & 826 \\
15 & $37^{\circ} 05^{\prime} \mathrm{N}, 16^{\circ} 52^{\prime} \mathrm{E}$ & $6 / 2196$ & $6 / 120$ & 100 & 369 \\
16 & $34^{\circ} 00^{\prime} \mathrm{N}, 18^{\circ} 00^{\prime} \mathrm{E}$ & $6 / 17 / 96$ & $6 / 130$ & 100 & 207 \\
17 & $36^{\circ} 00^{\prime} \mathrm{N}, 18^{\circ} 45^{\prime} \mathrm{E}$ & $6 / 2 / 96$ & $6 / 120$ & 110 & 324 \\
18 & $36^{\circ} 00^{\prime} \mathrm{N}, 20^{\circ} 20^{\prime} \mathrm{E}$ & $6 / 3 / 96$ & $6 / 90$ & 80 & 198 \\
19 & $34^{\circ} 00^{\prime} \mathrm{N}, 22^{\circ} 00^{\prime} \mathrm{E}$ & $6 / 15 / 96$ & $6 / 100$ & 90 & 414 \\
20 & $36^{\circ} 00^{\prime} \mathrm{N}, 22^{\circ} 15^{\prime} \mathrm{E}$ & $6 / 4 / 96$ & $6 / 90$ & 70 & 350 \\
21 & $34^{\circ} 00^{\prime} \mathrm{N}, 26^{\circ} 00^{\prime} \mathrm{E}$ & $6 / 13 / 96$ & $6 / 140$ & 120 & 270 \\
22 & $34^{\circ} 00^{\prime} \mathrm{N}, 30^{\circ} 00^{\prime} \mathrm{E}$ & $6 / 11 / 96$ & $6 / 130$ & 90 & 279 \\
23 & $34^{\circ} 00^{\prime} \mathrm{N}, 32^{\circ} 00^{\prime} \mathrm{E}$ & $6 / 9 / 96$ & $12 / 200$ & 110 & 309 \\
& & & & & \\
\hline & & & & & \\
\end{tabular}

infraciliature, the basis of alpha-level ciliate taxonomy (Corliss 1979), is known for very few species (e.g., Choi et al. 1992, Petz \& Foissner 1993), some tintinnid species are apparently capable of expressing different lorica morphologies (e.g., Gold \& Morales 1976, Davis 1981, Laval-Peuto 1983, Wasik \& Mikolajczyk 1994, Wasik 1998). In the present study, this potential problem should be minor as studies of field populations have rarely shown co-existence of different lorica morphotypes of the same species. Furthermore, no attempt is made here to provide absolute estimates of species richness but rather a comparison of different sites using limited sample volumes.

Chlorophyll concentrations were determined using a Turner Designs fluorometer to measure acetoneextracted chlorophyll retained by GF/F filters for the Mesoscale 93 samples. For the Minos cruise samples, pigments retained by $\mathrm{GF} / \mathrm{F}$ filters and extracted using methanol were measured using HPLC as detailed in Vidussi et al. (1996).

For each station, tintinnid data from all depths were pooled. This was done because preliminary analysis of all the stations showed no discernable trends with depth of tintinnid concentrations, species diversity, or community averaged morphological characteristics, similar to our previous findings for the NW Mediterranean (Cariou et al. 1999). Pooling data also provided a larger number of individuals from which to make population estimates. For each station the following parameters were calculated based on the pooled tintinnid data: numbers of species, numbers of genera, the Shannon diversity index (ln-based), overall community averages and standard deviations of lorica oral diameter and total lorica length. Additional parameters were depth-integrated chlorophyll and tintinnid concentrations calculated using the trapezoidal method and the depth of the chlorophyll maximum simply taken as the depth with the maximum concentration of chlorophyll. The depth of the chlorophyll maximum corresponds closely to the depth of the euphotic zone in the Mediterranean Sea (e.g., Dolan et al. 1999, Table 1). Regression and correlation analyses were run using Statview 6; probabilities for the correlation matrix were calculated using the Fisher $\mathrm{r}$ to $\mathrm{z}$ method. 


\section{RESULTS}

Tintinnid concentrations averaged about 25 cells $1^{-1}$ and while some high concentrations were found in western stations (Fig. 1), tintinnid concentrations did not show a clear west to east trend. In contrast, the data show a clear west to east decline in chlorophyll concentration (from an avarage of about 450 to $100 \mathrm{ng} \mathrm{l}^{-1}$ ) and increase in depth of the chlorophyll maximum from about 40 to $100 \mathrm{~m}$ depth. West to east trends were also evident in measures of tintinnid diversity. From the western-most stations of the Catalan Sea to the eastern stations in the Levatine Basin, the number of
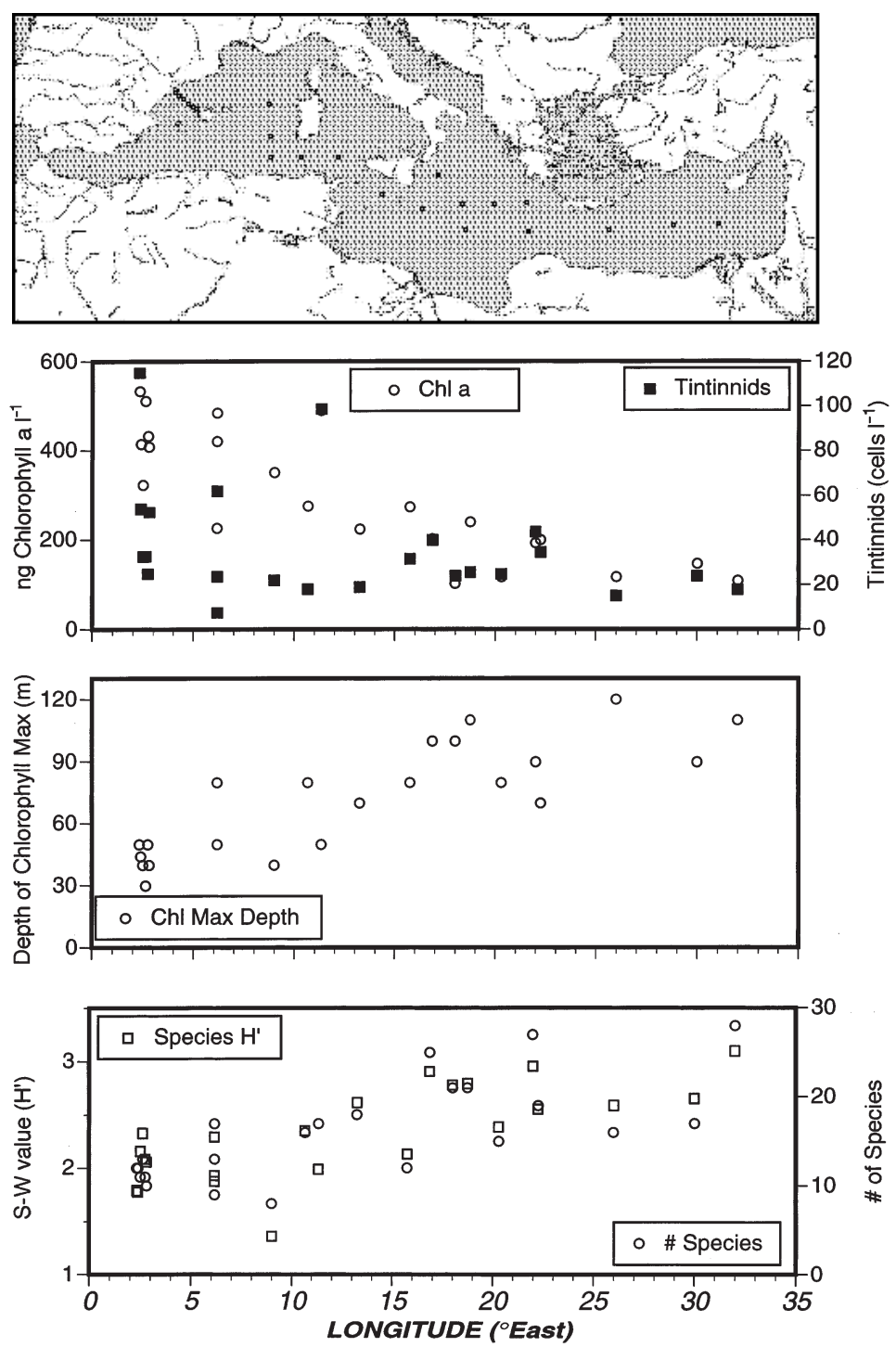

Fig. 1. Longitudinal trends of average water column chlorophyll and tintinnid concentrations, depth of the chlorophyll maximum, tintinnid species abundances and diversity. Statistical relationships are given in Table 2. Top panel shows approximate station locations, station data appear in Table 1 species found per station increased from about 10 to 25 , and the value of diversity metric $H^{\prime}$ increased from 2 to 3 (Fig. 1). Similar trends were evident for numbers of genera and values of $H^{\prime}$ calculated using using generic data (data not shown). There were also west to east trends in metrics of tintinnid morphology. Community averages of lorica oral diameter increased from about 28 to $38 \mu \mathrm{m}$ and overall lorica length increased from 70 to $140 \mu \mathrm{m}$ (Fig. 2). Variability in morphology within tintinnid communities also appeared to increase from west to east as indicated by larger standard deviations in average lorica length among eastern compared to western stations (Fig. 2).

Statistical relationships revealed close covariation of several measures of tintinnid taxonomic diversity and morphology with chlorophyll concentration and distribution. The depth of the chlorophyll maximum was positively related to numbers of species, genera, $H^{\prime}$ values, average lorica diameter, average lorica length and standard deviations of lorica length. Average chlorophyll concentration was negatively related to the depth of the chlorophyll maximum as well as measures of tintinnid taxonomic diversity and morphology (Table 2). Measures of diversity (numbers of species, genera, $H^{\prime}$ values) were positively related to average community lorica diameter and length as well as community variability in lorica length but not variability in oral diameter.

Larger scale shifts than station-to-station shifts in tintinnid community composition were examined using a species-area curve. A total of 90 species of tintinnids were found by pooling the data from all 23 stations (Table 3 ). Plotting the cumulative number of species as a function of individuals examined from the western to the eastern stations (Fig. 3) showed 2 distinct discontinuities in the relation of 'species as a function of individuals'. The 2 relatively abrupt increases in number of species encountered, presumably indicating faunal breaks, corresponded to the transition from the Catalan Sea to the central western basin and then again from the western basin to the central basin. The Catalan Sea community (Stns 1 to 6) can be described as an assemblage dominated by Stensomella species. In the western basin community (Stns 7 to 14), dominance shifts to Acanthostomella species. With the transition from the western basin to the central and eastern basins, species of the genus Salpingacantha become relatively more important. 

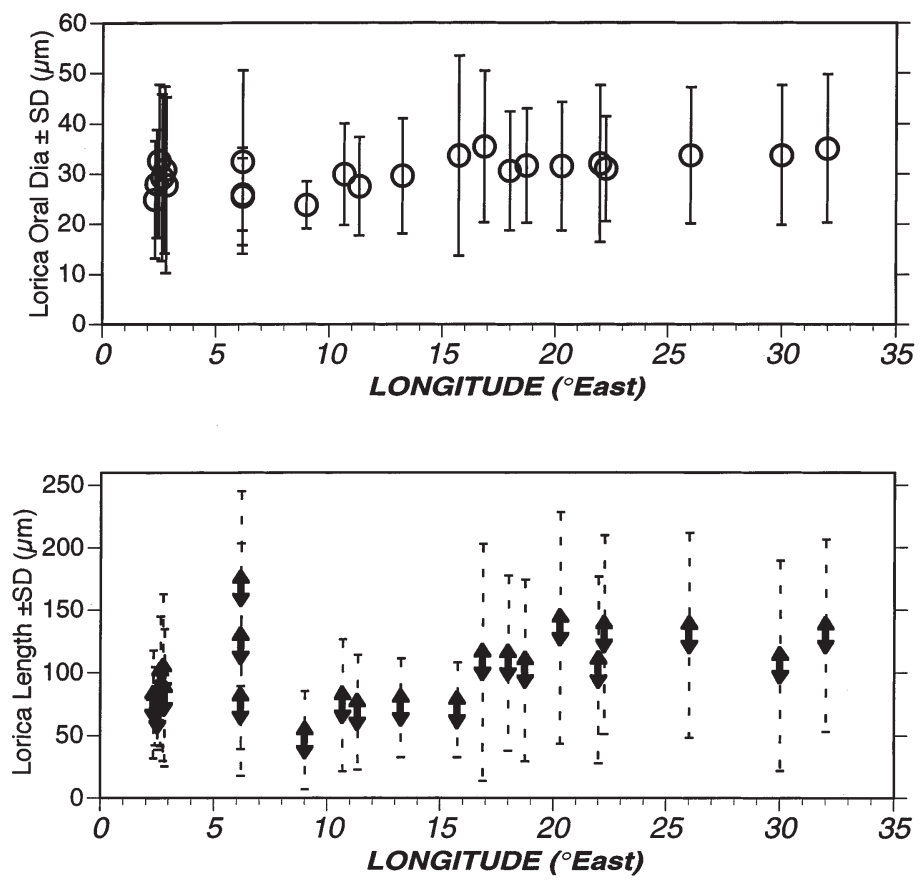

Fig. 2. Longitudinal trends in tintinnid lorica dimensions. Community averages of (a) lorica oral diameter and (b) overall length. Error bars show standard deviations. Statistical relationships are given in Table 2

from west to east with declines in chlorophyll concentration and the depth of the chlorophyll maximum layer (Fig. 1, Table 2).

Both the general trend and magnitude of the diversity gradient (an increase from 10 to 30 species with a chlorophyll decrease from about 400 to $100 \mathrm{ng} \mathrm{l}^{-1}$ ) agree with the few comparative data which exist from the Atlantic. Specifically, along a south to north transect of 16 stations between 58 and $34^{\circ} \mathrm{S}$ at about $53^{\circ} \mathrm{W}$ in the austral spring, numbers of tintinnid species per station increase from 9 to 34 and correspond with decreases in average chlorophyll concentrations from approximately 1000 to $200 \mathrm{ng} \mathrm{l}^{-1}$ (appendix species list and Fig. 2 in Thompson et al. 1999). Similarly, recently constructed maps of the species abundance of planktonic foraminifera show, for the same area of the Atlantic Ocean, a south to north increase from about 10 to 20 species (Fig. 2a in Rutherford et al. 1999).

For planktonic foraminifera, large-scale gradients in oceanic diversity are relatable to annual average sea surface temperature, which serves as a proxy measure of water column structure; the relationship is strong enough to permit prediction of numbers of foraminifera species from sea surface temperature alone (Rutherford et al.

\section{DISCUSSION}

The gradient of 'trophic state' found in the world ocean from high to low latitudes is found in the Mediterranean Sea from west to east, albeit of smaller magnitude. Nutrient concentrations are lower in the eastern compared to the western basins (Bethoux et al. 1992) and nutrient limitation increases from west to east (Krom et al. 1991). Chlorophyll concentrations and primary production decline from west to east (e.g., Antoine et al. 1996, Williams 1998). In the Mediterranean Sea, diversity among tintinnids, measured as numbers of species, genera, or $H^{\prime}$ values, increases 1999). Somewhat surprisingly, the relationship established for foraminifera between annual average sea surface temperature and species abundance (presumably annual as well) provides relatively robust estimates of tintinnid species abundance in the SW Atlantic during the austral spring, using water temperature at the time of sampling, in waters ranging from about 0 to $20^{\circ} \mathrm{C}$ (Fig. 4). However, not surprisingly, in the Mediterranean, as sea surface temperature in early summer varies within a very narrow range (17.5 to $23^{\circ} \mathrm{C}_{i}$ see Dolan et al. 1999) it is a poor predictor of species abundance. Nonetheless, tintinnid species diversity in the Mediterranean is clearly relatable to water col-

Table 2. Correlation matrix of biological variables: number of species (\# sp.), number of genera (\# gn), Shannon species diversity index $\left(H^{\prime}\right)$, community average lorica oral diameter (LOD), standard deviation of LOD (LOD SD), community average lorica length (LL), standard deviation of LL (LL SD), average chlorophyll concentration (Avg chl) and depth of the chlorophyll maximum (Chl max. Z). For all correlations, $\mathrm{n}=23$, values in bold are significant at probability levels of ${ }^{*} 0.05,{ }^{* *} 0.01,{ }^{* * *} 0.001$ or ${ }^{* * * *} 0.0001$

\begin{tabular}{|c|c|c|c|c|c|c|c|c|}
\hline & \# sp. & \# gn & $H^{\prime}$ & LOD & LOD SD & LL & LL SD & Avg chl \\
\hline \# gn & $0.91^{* * * *}$ & - & & & & & & \\
\hline$H^{\prime}$ & $0.89^{* * * *}$ & $0.89^{* * * *}$ & - & & & & & \\
\hline LOD & $0.63^{* * *}$ & $0.64^{* * *}$ & $0.80^{* * * *}$ & - & & & & \\
\hline LOD SD & 0.17 & 0.20 & 0.38 & $0.64^{* * *}$ & - & & & \\
\hline LL & $0.44^{*}$ & 0.34 & $0.54^{* *}$ & $0.51^{*}$ & 0.34 & - & & \\
\hline LL sd & $0.52^{*}$ & $0.49^{*}$ & $0.60^{* *}$ & $0.47^{*}$ & 0.15 & $0.83^{* * * *}$ & - & \\
\hline Avg chl & $-0.55^{* *}$ & $-0.52^{*}$ & $-0.70^{* * * *}$ & $-0.60^{* *}$ & -0.04 & $-0.46^{*}$ & $-0.59^{* *}$ & - \\
\hline Chl max. Z & $0.68^{* * *}$ & $0.66^{* * *}$ & $0.76^{* * * *}$ & $0.61^{* *}$ & 0.06 & $0.47^{*}$ & $0.64^{* * *}$ & $-0.85^{* * * *}$ \\
\hline
\end{tabular}




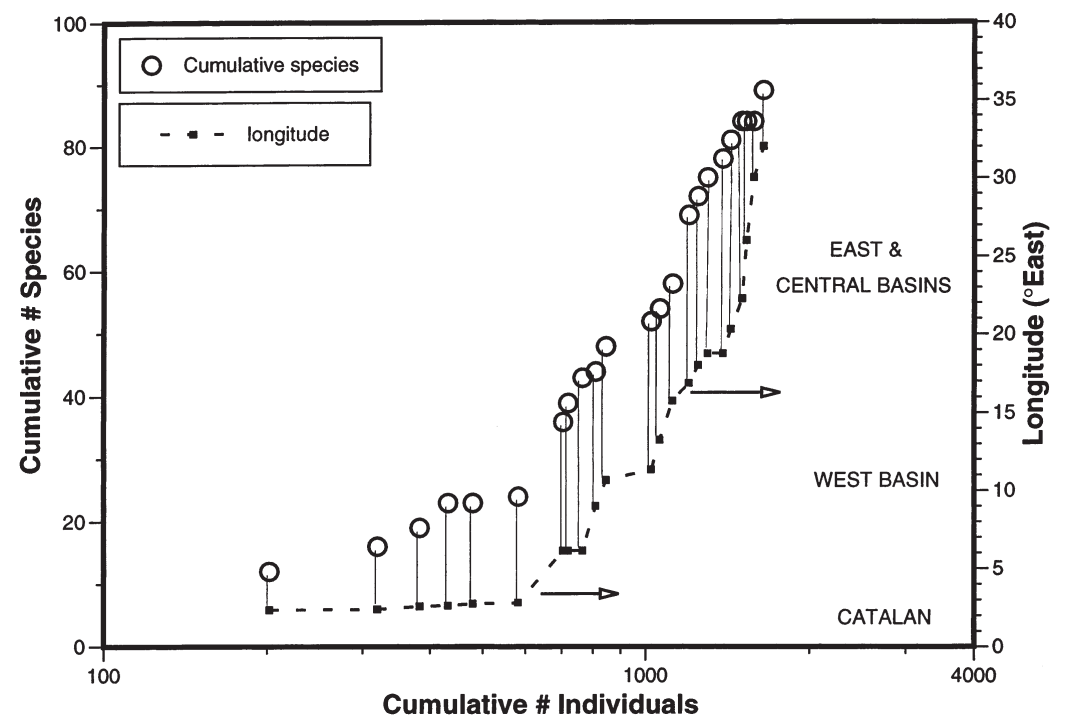

Fig. 3. Species area curve showing cumulative species as a function of individual examined, station by station, arranged from west to east. Note the 2 large apparent faunal breaks indicated by breaks in the curve: (1) between stations in the Catalan Sea and those in the Western Basin and (2) between Western Basin stations and those of the Central and Eastern Basins. Both faunal breaks consisted of the appearance of 4 species from one station to the next

umn structure, measured directly as depth of the chlorophyll maximum. Given that tintinnids are typical of the plankton, west-east differences in water column structure in the Mediterranean appear to be accompanied by differences in planktonic diversity, much like the north-south gradients of oceanic systems.
While the existence of diversity gradients in oceanic plankton is well known (e.g., Rohde 1992), our understanding of factors underlying pelagic biodiversity has been described rather accurately as 'vague' (Smetacek 1996). Thus, the paradox of planktonic diversity (Hutchinson 1961) remains to a large extent paradoxical.

Table 3. Tintinnids species encountered. ${ }^{*}$ Common species ( $>1 \%$ total cells)

\begin{tabular}{|c|c|c|c|c|}
\hline $\begin{array}{l}\text { Acanthostomella } \\
\text { A. conicoides* } \\
\text { A. gracilis } \\
\text { A. lata } \\
\text { A. minutissima } \\
\text { A. obtusa* } \\
\text { Amphorella } \\
\text { A. gaarderae* } \\
\text { A. lackmanni* } \\
\text { A. quadrilineata* } \\
\text { Ascampbellielia } \\
\text { A. acuta } \\
\text { Canthariella } \\
\text { C. pyramidata* } \\
\text { C. septinaria } \\
\text { Climacocylis } \\
\text { C. scalaria } \\
\text { C. scalaroides } \\
\text { Codonella } \\
\text { C. amphorella } \\
\text { C. galea } \\
\text { C. nationalis }\end{array}$ & $\begin{array}{l}\text { Craterella } \\
\text { C. oxyura } \\
\text { C. tortulata* } \\
\text { C. urceolata } \\
\text { Cyttarocylis } \\
\text { C. encecryphalus } \\
\text { Dadayiella } \\
\text { D. ganymedes* } \\
\text { D. pachytoecus* } \\
\text { Daturella } \\
\text { D. angusta } \\
\text { Dictyocysta } \\
\text { D. elegans } \\
\text { D. lepida } \\
\text { D. magna } \\
\text { D. minor } \\
\text { D. mitra* } \\
\text { D. mulleri } \\
\text { Epiplocylis } \\
\text { E. acuminata } \\
\text { E. undella } \\
\text { Epiorella } \\
\text { E. healdi }\end{array}$ & $\begin{array}{l}\text { Eutintinnus } \\
\text { E. inquilinus } \\
\text { E. fraknoi } \\
\text { E. lusus-undae* } \\
\text { E. macilentus } \\
\text { E. pectina } \\
\text { E. tenuis } \\
\text { E. tubulosis } \\
\text { Eutintinnus sp. a } \\
\text { Favella } \\
\text { F. azorica } \\
\text { F. serrata } \\
\text { Metacylis } \\
\text { M. jörgensenii } \\
\text { Metacylis sp. a } \\
\text { Ormosella } \\
\text { O. trachelium } \\
\text { Parundella } \\
\text { P. laachmanni } \\
\text { Petalotricha } \\
\text { P. serrata } \\
\text { P. major } \\
\text { Proplectella } \\
\text { P. perpusilla } \\
\text { P. globulosa }\end{array}$ & $\begin{array}{l}\text { Protorhabdonella } \\
\text { P. curta* } \\
\text { P. simplex } \\
\text { Rhabdonella } \\
\text { R. amor } \\
\text { R. apophysata } \\
\text { R. elegans } \\
\text { R. spiralis } \\
\text { Rhabdosella } \\
\text { R. cuneolata } \\
\text { Salpingacantha } \\
\text { S. acuminata* } \\
\text { S. curta } \\
\text { S. decurtata* } \\
\text { S. faurie* } \\
\text { S. perca } \\
\text { S. unquiculata } \\
\text { Salpingella } \\
\text { S. gracilis } \\
\text { S. minuta* } \\
\text { S. laminata } \\
\text { Steenstrupiella } \\
\text { S. intumescens } \\
\text { S. gracilis } \\
\text { S. steenstrupi* }\end{array}$ & $\begin{array}{l}\text { Stensomella } \\
\text { S. nivalis* } \\
\text { S. steini* } \\
\text { Tintinnopsis } \\
\text { T. parva } \\
\text { Undella } \\
\text { U. aculeata } \\
\text { U. caudata } \\
\text { U. claparedei } \\
\text { U. clevei* } \\
\text { U. hyalina } \\
\text { U. subacuta* } \\
\text { U. turida } \\
\\
\text { Undellopsis } \\
\text { U. marsupila } \\
\text { Xystonella } \\
\text { X. lanceolata } \\
\text { X. longicaudata } \\
X . \text { lohmanni } \\
\text { X. paradoxa } \\
\text { X. treforti } \\
\\
\text { Xystonelopsis } \\
\text { X. brandti } \\
\text { X. constricta } \\
\text { X. cymatica } \\
X . \text { paradoxi } \\
\text { X. pinnata }\end{array}$ \\
\hline
\end{tabular}


For example, increases in planktonic diversity with increasing water column structure have been explained as resulting from the potential existence of a larger number of distinct ecological niches along the vertical axis (Rutherford et al. 1999). However appealing an explanation this sounds, the underlying mechanism remains undefined and the obvious candidate of trophic specialisation may not be dominant. Analyses of copepod community structures suggest that trophic specialisation may be much less important than predation in maintaining diversity, and predation pressure simply may be stronger in a structured compared to a well-mixed water column (e.g., McGowan \& Walker 1979, 1985, Longhurst 1985).

It should be recalled that correlations of environmental parameters with gradients of diversity often have little explanatory power (Rohde 1999). For example, the north-south gradient in foraminiferal diversity is best correlated with annual average sea surface temperature as are the diversity gradients of marine bivalves of both the epifauna and infauna (Roy et al. 1999). Thus, while sea surface temperature may be related to water column structure and the latter may influence planktonic diversity, it is not obvious how water column structure could influence diversity of both surface-dwelling and burrowing bivalves.

Clearly, different mechanisms may act simultaneously or perhaps sequentially, rendering a search for a dominant factor difficult or futile. Nonetheless, it is worthwhile considering lines of evidence, such as shifts in morphologies linked to shifts in diversity, which potentially can help identify important factors influencing diversity.

Overall, in the Mediterranean, diversity increased with the community averages of lorica dimensions (Table 2). From west to east, community averages of lorica oral diameters increased from about 28 to $38 \mu \mathrm{m}$ and lorica length averages from roughly 70 to $140 \mu \mathrm{m}$ (Fig. 2). Thus, diverse communities were, on average, composed of larger individuals. Interestingly, the differences in morphological characteristics were not large compared to seasonal changes known from single localities. The west-east difference in oral diameter of $10 \mu \mathrm{m}$ is modest compared to $20 \mu \mathrm{m}$, which is typical for seasonal changes in average lorica diameter in a variety of systems, i.e., the Bay of Fundy (Middlebrook et al. 1987), Narragansett Bay (Verity 1987), and Jamaican coastal waters (Gilron et al. 1991).

Seasonal shifts in tintinnid species compositions yield changes in average oral diameter and have been linked to corresponding changes in size of the phyto-

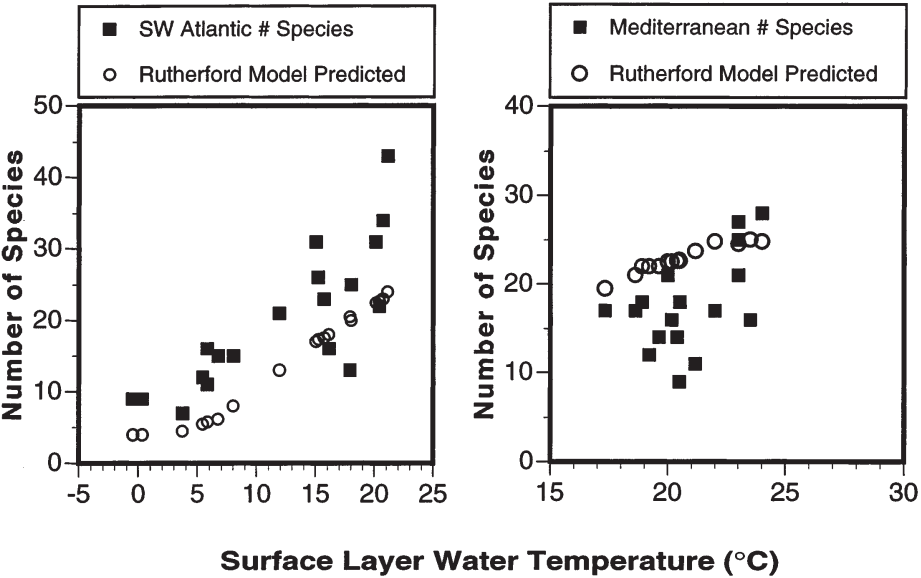

Fig. 4. Plots of tintinnid species abundance as a function of water temperature at $5 \mathrm{~m}$ for the SW Atlantic Ocean during the austral spring (data from Thompson et al. 1999) and the Mediterranean Sea during spring (this study), compared to predicted number of species from the 'Species vs Sea Surface Temperature' of Rutherford et al. (1999, their Fig. 2b) established for foraminifera based on satellitemeasured annual sea surface temperature. The Rutherford et al. (1999) relationship was based on annual averages for sea surface temperature and, although unstated, presumably total foraminifera species present over an annual cycle. Note that the Rutherford model provides reasonable estimates of tintinnid springtime species numbers for the SW Atlantic but not for the Mediterranean, in which surface temperature variation is relatively small. Rutherford model estimates were obtained graphically as no equation was given

plankton prey of tintinnids. Thus, the seasonal appearance of larger species occurs with increases in the average sizes of prey available to tintinnids (Middlebrook et al. 1987, Verity 1987). However, it is difficult to ascribe west to east increases in oral diameter among Mediterranean populations to changes in average prey size as average prey size likely decreases. Based on phytoplankton pigment data from May-June 1996, average phytoplankton cell size is probably smaller in the east compared to the west because marker pigments characteristic of nano- and picophytoplankton are relatively invariant compared to the west to east declines in chlorophyll stocks (Dolan et al. 1999). Variability in oral diameters was unrelated to taxonomic diversity (Table 2), similar to previous findings concerning a single site (Cariou et al. 1999). In sum, while data on lorica diameters support the idea that trophic specialisation exists among tintinnids (e.g., seasonal changes in linked to changes in prey communities in Narrangansett Bay, Verity 1987), they also suggest that it is not the dominant factor underlying Mediterranean tintinnid diversity.

Among Mediterranean tintinnids, taxonomic diversity is related to morphological variability in the form of lorica length across both large geographic scales 
(Table 2) and short temporal scales (Cariou et al. 1999). Predation was hypothesized as possibly responsible for generating heterogeneity in lorica lengths; the suggestion was based on published data concerning feeding in copepods of the genus Arcartia showing that medium-sized tintinnids may be subject to predation more than small or large tintinnids (Cariou et al. 1999). Unfortunately, we cannot evaluate the possibility that tintinnids are subjected to different degrees of predation pressure in the western compared to the central or eastern Mediterranean, due to a lack of data on copepod abundances. To our knowledge, a single large spatial scale study has been conducted and concerned only the central and eastern basins in autumn; there was little difference in the copepod abundances or community composition between central and eastern stations (Sioukou-Frangou et al. 1997). However, in the central and eastern Mediterranean copepod communities, the generally omnivorous or predacious cyclopoid and poecilostomatid copepods, which are likely tintinnid predators, were relatively abundant, similar to tropical communities (Sioukou-Frangou et al. 1997).

It should be noted that with regard to diversity it is often difficult to distinguish between explanations and byproducts (e.g., Kolasa et al. 1998). Clearly many different mechanisms may underlie diversity in tintinnids and they may be difficult to detect if they operate at small temporal and spacial scales, as is hypothesized to be the case for phytoplankton in the central North Pacific (Venrick 1990). However, the general relationship found in oceanic systems linking increased diversity to increases in water column structure holds true for the Mediterranean Sea and diversity appears relatable to a particular water column feature-depth of the chlorophyll maximum.

It is also worth recalling that relationships considered here are of a specific time (seasonal), space (100s of $\mathrm{km}$ ) and taxonomic scale (species within a single suborder) within a single system. Different relationships concerning diversity are apparent depending on the scales considered. For example, relationships between resource availability and diversity vary with scale. On a geological time scale, plankton diversity has been positively associated with increases in 'trophic state' of seas from an oligotrophic Devonian to the eutrophic Paleozoic (Martin 1996). In comparing different systems, among present-day freshwater communities, there is a strong negative relationship between nutrient concentrations and diversity of both phytoplankton and zooplankton (e.g., Liebold 1999). Within a single species, 'cryptic species' (morphologically similar but genetically distinct forms) of the foraminfera Orbulina universe, 3 different forms appear in waters of different chlorophyll concentrations from north to south in the Atlantic Ocean (De Vargas et al. 1999). Diverse populations (different forms co-existing) occur in areas bracketing relatively low surface chlorophyll concentrations of $100 \mathrm{ng} \mathrm{l}^{-1}$ (De Vargas et al. 1999).

Can findings with regard to tintinnid ciliates in the Mediterranean be generalized to other planktonic organisms? This remains to be established. Actual species abundance patterns of tintinnids and those predicted for foraminifera appear to be similar in the south Atlantic (Fig. 4). However, in the Mediterranean Sea, species abundances of foraminifera, in contrast with tintinnids, do not appear to increase from west to east but rather are maximal in the central basin - both in late summer with stratified water columns and in winter when water columns are mixed (Pujol \& Vergnaud Grazzini 1995). Hence it appears that, even among planktonic protists, processes or factors influencing diversity likely differ between groups.

Acknowledgements. Financial support for this study was provided by the Centre Nationale de la Recherche Scientifique, Université Paris VI, and the Smithsonian Institution Office of Fellowships and Grants. The efforts of 4 anonymous reviewers, whose comments led to improvements in the manuscript, are gratefully acknowledged.

\section{LITERATURE CITED}

Antoine D, André JM, Morel A (1996) Oceanic primary production. 2. Estimation at global scale from satellite (coastal zone color scanner) chlorophyll. Glob Biogeochem Cycles 10:57-69

Balech E (1959) Tintinoinea del Mediterraneo. Instituto Espanol de Oceanografia, Madrid

Bethoux JP, Morin P, Madec C, Gentili B (1992) Phosphorous and nitrogen behaviour in the Mediterranean Sea. DeepSea Res 39:1641-1654

Bethoux JP, Gentili B, Taillez D (1998) Warming and freshwater budget change in the Mediterranean since the 1940s, their possible relation to the greenhouse effect. Geophys Res Lett 25:1023-1026

Campbell AS (1942) The oceanic Tintinnoina of the plankton gathered during the last cruise of the Carnegie. Carnegie Institution of Washington Publication 537, Washington, DC

Capriulo GM (1982) Feeding of field collected tintinnid microzooplankton on natural food. Mar Biol 71:73-86

Capriulo GM, Carpenter EJ (1983) Abundance, species composition and feeding impact of tintinnid microzooplankton in central Long Island Sound. Mar Ecol Prog Ser 10: 277-288

Cariou JB, Dolan JR, Dallot S (1999) A preliminary study of tintinnid diversity in the NW Mediterranean Sea. J Plankton Res 21:1065-1075

Caron DA, Dennett MR (1999) Phytoplankton growth and mortality during the 1995 Northeast Monsoon and Spring Intermonsoon in the Arabian Sea. Deep-Sea Res II 46: 1665-1690

Choi JK, Coats DW, Brownlee DC, Small EB (1992) Morphology and infraciliature of three species of Eutintinnus (Ciliophora: Tintinnia) with guidelines for interpreting protargol-stained tintinnine ciliates. J Protozool 39:80-92 
Corliss JO (1979) The ciliated protozoa, characterisation, classification and guide to the literature, 2nd edn., Pergamon Press, Oxford

Davis CC (1981) Variations of lorica shape in the genus Pytochocylis (Protozoa: Tintinnia) in relation to species identification. J Plankton Res 3:433-443

De Vargas C, Norris R, Zaninette L, Gibb, SW, Pawlowski J (1999) Molecular evidence of cryptic speciation in planktonic foraminfers and their relation to oceanic provinces. Proc Natl Acad Sci USA 96:2864-2868

Dolan JR, Marrasé C (1995) Planktonic ciliate distribution relative to a deep chlorophyll maximum: Catalan Sea, N.W. Mediterranean, June 1993. Deep-Sea Res 42:1965-1987

Dolan JR, Vidussi F, Claustre H (1999) Planktonic ciliates in the Mediterranean Sea: longitudinal trends. Deep-Sea Res 46:2025-2039

Gilron GL, Lynn DH, Roff JC (1991) The annual cycle of biomass and production on a tropical neritic region near Kingston, Jamaica. Mar Microb Food Webs 5:95-113

Gifford DJ, Fessenden LM, Garrahan PR, Martin E (1995) Grazing by microzooplankton and mesozooplankton in the high-latitude North Atlantic Ocean: spring versus summer dynamics. J Geophys Res C4 100:6665-6675

Gold K, Morales E (1976) Studies on the sizes, shapes, and the development of the lorica of agglutinated tintinnida. Biol Bull 150:377-392

Heinbokel JF (1978) Studies on the functional role of tintinnids in the southern California Bight. I. Grazing and growth rates in laboratory cultures. Mar Biol 47:177-189

Heinbokel JF, Beers JR (1979) Studies on the functional role of tintinnids in the southern California Bight III. Grazing impact of natural assemblages. Mar Biol 52:23-32

Hutchinson GE (1961) The paradox of the plankton. Am Nat 95:137-144

Jörgensen E (1924) Mediterranean tintinnidae. Report of the Danish Oceanographic Expeditions 1908-1910 to the Mediterranean and adjacent seas. Vol II, Biology, No. 8, J3, Thor Expedition, Copenhagen

Kofoid CA, Campbell AS (1929) A conspectus of the marine and fresh-water ciliata belonging to the suborder tintinnoinea, with descriptions of new species principally from the Agassiz expedition to the eastern tropical Pacific 1904-1905. Univ Calif Publ Zool 34:1-403

Kofoid CA, Campbell AS (1939) The Tintinnoinea of the eastern Tropical Pacific. Bull Mus Comp Zool Harv Coll 84: $1-473$

Kolasa J, Hewitt CL, Drake JA (1998) Rapoport's rule: an explanation or a byproduct of the latitudinal gradient in species richness? Biodivers Conserv 7:1447-1455

Krom MD, Kress N, Brenner S, Gordon LI (1991) Phosphorous limitation of primary production in the eastern Mediterranean Sea. Limnol Oceanogr 36:424-432

Laval-Peuto M (1983) Sexual reproduction in Favella ehrenbergii (Ciliophora, Tintinnia) taxonomical implications. Protististologica 19:503-512

Liebold MA (1999) Biodiversity and nutrient enrichment in pond plankton communities. Evol Ecol Res 1:73-95

Longhurst A (1985) Relationship between diversity and the vertical structure of the upper ocean. Deep-Sea Res 32: $1535-1570$

Martin RE (1996) Secular increases in nutrient levels through the Phanerozoic: implications for productivity, biomass, and diversity of the marine biosphere. Palaios 11:209-219

McGowan JA, Walker PW (1979) Structure in the copepod community of the North Pacific central gyre. Ecol Monogr 49:195-226

McGowan JA, Walker PW (1985) Dominance and diversity maintenance in an oceanic ecosystem. Ecol Monogr 55: 103-118

Middlebrook K, Emerson CW, Roff JC, Lynn DH (1987) Distribution and abundance of tintinnids in the Quoddy Region of the Bay of Fundy. Can J Zool 65:594-601

Montagnes DWS, Lynn DH (1987) A quantitative protargol stain (QPS) for ciliates: a description of the method and tests of its quantitative nature. Mar Microb Food Webs 2: 83-93

Montagnes DJS, Lynn DH (1991) Taxonomy of choreotrichs, the major marine planktonic ciliates, with emphasis on the aloricate forms. Mar Microb Food Webs 5:59-74

Petz W, Foissner W (1993) Morphogenesis in some freshwater tintinnids (Ciliophora, Oligotrichida). Eur J Protistol 29: 106-120

Pierce RW, Turner JT (1992) Ecology of planktonic ciliates in marine food webs. Rev Aquat Sci 6:139-181

Pierce RW, Turner JT (1993) Global biogeography of marine tintinnids. Mar Ecol Prog Ser 94:11-26

Pomeroy LR (1974) The ocean's food web, a changing paradigm. Bioscience 24:499-504

Pujol C, Vergnaud Grazzini C (1995) Distribution patterns of live planktic foraminifers as related to regional hydrography and productive systems of the Mediterranean Sea. Mar Micropaleontol 25:187-217

Rassoulzadegan F (1978) Dimensions et taux d'ingestion des particules consommés par un tintinnide: Favella ehrenbergii. Ann Inst Océanogr Paris 54:17-24

Rassoulzadegan F, Etienne M (1981) Grazing rate of the tintinnid Stensomella ventricosa (Clap. \& Lachm.) Jörg. on the spectrum of naturally occurring particulate matter from a Mediterranean neritic area. Limnol Oceanogr 26: $258-270$

Rohde K (1992) Latitudinal gradients in species diversity: the search for the primary cause. Oikos 65:514-527.

Rohde K (1999) Latitudinal gradients in species diversity and Rapoport's rule revisited: a review of recent work and what can parasites teach us about the causes of the gradients. Ecography 22:593-613

Robertson JR (1983) Predation by estuarine zooplankton on tintinnid ciliates. Estuar Coast Shelf Sci 16:27-36

Roy K, Jablonski D, Valentine JW (1999) Dissecting latitudinal diversity gradients: functional groups and clades of marine bivalves. Proc R Soc Lond B 267:293-299

Rutherford S, D'Hondt S, Prell W (1999) Environmental controls on the geographic distribution of zooplankton diversity. Nature 400:750-753

Siokou-Frangou I, Christou ED, Fragopoulu N, Mazzocchi MG (1997) Mesozooplankton distribution from Sicily to Cyprus (Eastern Mediterranean): II. Copepod assemblages. Oceanol Acta 20:537-548

Smetacek V (1996) Biodiversity and production in the water mass. In: Hempel G (ed) The ocean and the poles. Gustav Verlag, Jena, p 207-216

Spittler P (1973) Feeding experiments with tintinnids. Oikos 15:128-132

Stoecker DK, Sanders NK (1985) Differential grazing by Acartia tonsa on a dinoflagellate and a tintinnid. J Plankton Res 7:85-100

Stoecker DK, Guillard RRI, Kavee RM (1981) Selective predation by Favella ehrenbergii (Tintinnia) on and among dinoflagellates. Biol Bull 160:136-145

Stoecker DK, Davis L, Provan L (1983) Growth of Favella sp. (Ciliata: Tintinnia) and other micro-zooplankters in cages incubated in situ and comparison to growth in vitro. Mar Biol 75:293-302

Thompson GA, Alder VA, Boltovskoy D, Brandini F (1999) 
Abundance and biogeography of tintinnids (Ciliophora) and associated microzooplankton in the Southwestern Atlantic Ocean. J Plankton Res 21:1265-1298

Turner JT, Anderson DM (1983) Zooplankton grazing during dinoflagellate blooms in a cape cod embayment, with observations of predation upon tintinnids by copepods. Mar Ecol 4:359-374

Venrick EL (1990) Phytoplankton in an oligotrophic ocean: species structure and interannual variability. Ecology 71: $1547-1563$

Verity PG (1985) Grazing, respiration, excretion and growth rates of tintinnids. Limnol Oceanogr 30:1268-1282

Verity PG (1987) Abundance, community composition, size distribution, and production rates of tintinnids in Narragansett Bay, Rhode Island. Estuar Coast Shelf Sci 24: 671-690

Editorial responsibility: Jed Fuhrman,

Los Angeles, California, USA
Vidussi F, Claustre H, Bustillo-Guzman J, Cailliau C, Marty JC (1996) Rapid HPLC method for determination of phytoplankton chemotaxonomic pigments: seperation of chlorophyll a from divinyl-chlorophyll a and zeaxanthin from lutein. J Plankton Res 18:2377-2382

Wasik A (1998) Antarctic tintinnids: their ecology, morphology, uultrastructure and polymorphism. Acta Protozool 37: 5-15

Wasik A, Mikolajczyk E (1994) Annual cycle of tintinnids in Admiralty Bay with an emphasis on seasonal variability in Cymatocylis affinis/convallaria lorica morphology. J Plankton Res 16:1-8

Williams N (1998) The Mediterranean beckons to Europe's oceanographers. Nature 279:483-484

Zietzschel B (1982) Zoogeography of pelagic marine protozoa. Ann Inst Océanogr Paris 58(S):91-116

Submitted: February 24, 2000; Accepted: April 27, 2000

Proofs received from author(s): June 6, 2000 